\title{
R-Reactor Disassembly Basin Radiation Survey and Sampling Plan
}

by

J. B. Pickett

Westinghouse Savannah River Company

Savannah River Site

Aiken, South Carolina 29808

This paper was prepared in connection with work done under the above contract number with the U.S. Department of Energy. By acceptance of this paper, the publisher and/or recipient acknowledges the U.S. Government's right to retain a nonexclusive, royalty-free license in and to any copyright covering this paper, along with the right to reproduce and to authorize others to reproduce all or part of the copyrighted paper.
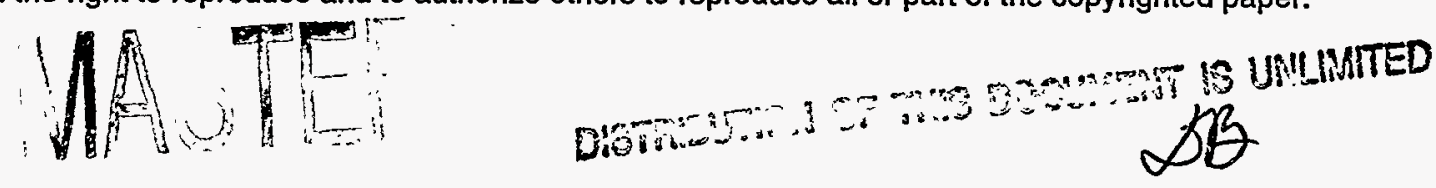


\section{DISCLAIMER}

This report was prepared as an account of work sponsored by an agency of the United States Government. Neither the United. States Government nor any agency thereof, nor any of their employees, makes any warranty, express or implied, or assumes any legal liability or responsibility for the accuracy, completeness, or usefulness of any information, apparatus, product, or process disclosed, or represents that its use would not infringe privately owned rights. Reference herein to any specific commercial product, process, or service by trade name, trademark, manufacturer, or otherwise does not necessarily constitute or imply its endorsement, recommendation, or favoring by the United States Government or any agency thereof. The views and opinions of authors expressed herein do not necessarily state or reflect those of the United States Government or any agency thereof.

This report has been reproduced directly from the best available copy.

Available to DOE and DOE contractors from the Office of Scientific and Technical Information, P.O. Box 62, Oak Ridge, TN 37831; prices available from (615) 576-8401.

Available to the public from the National Technical Information Service, U.S. Department of Commerce, 5285 Port Royal Road, Springfield, VA 22161. 


\section{DISCLAIMER}

Portions of this document may be illegible electronic image products. Images are produced from the best available original document. 
FDD-ENG-97-0044, Rev. 1

\section{R-REACTOR DISASSEMBLY BASIN \\ RADIATION SURVEYAND SAMPLING PLAN}

Prepared by J. B. Pickett

Facilities Decommissioning Division (FDD)

Engineering Department 
FDD Engineering

R-Disassembly Basin Radiation Survey and Sampling Plan
FDD-ENG-97-0044

Revision No.:-

August 18; 1997

Page 2 of $24.419 / 98$

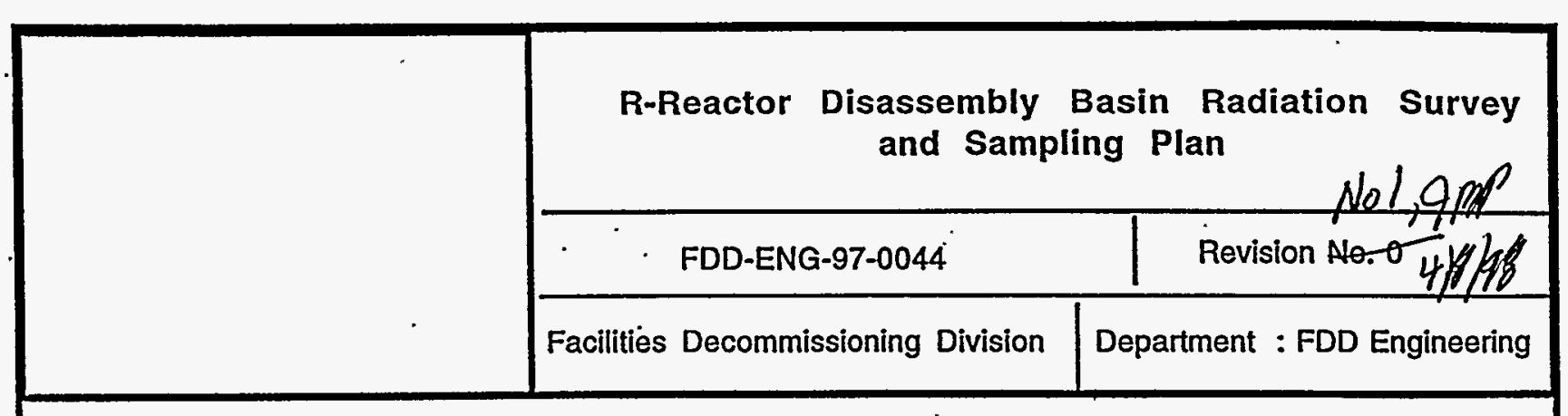

Approvals

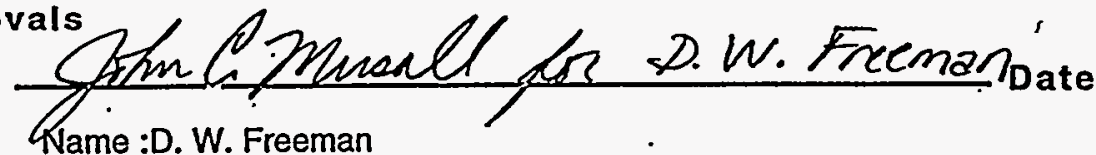
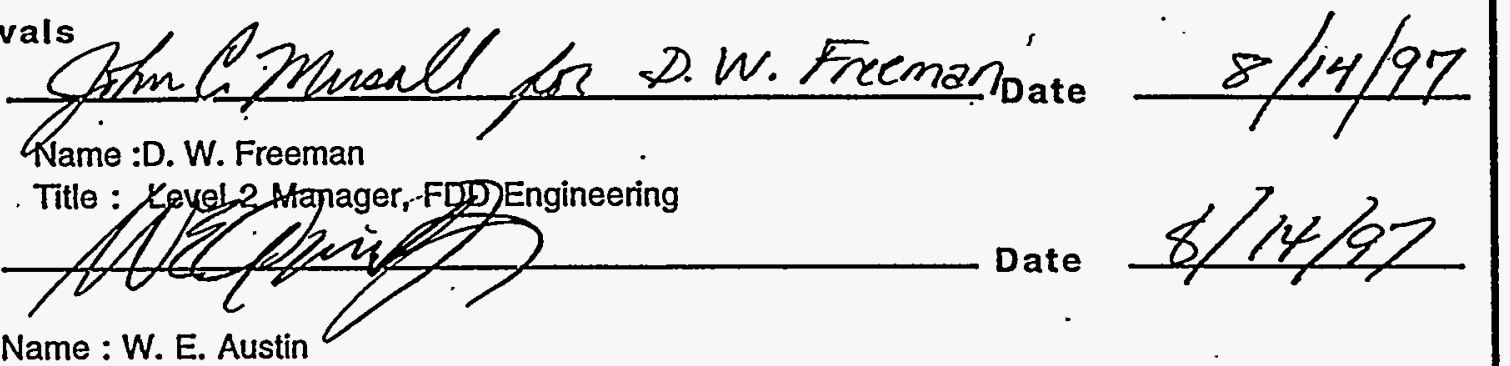

Title : Manager, FDD Engineering

Reviewers

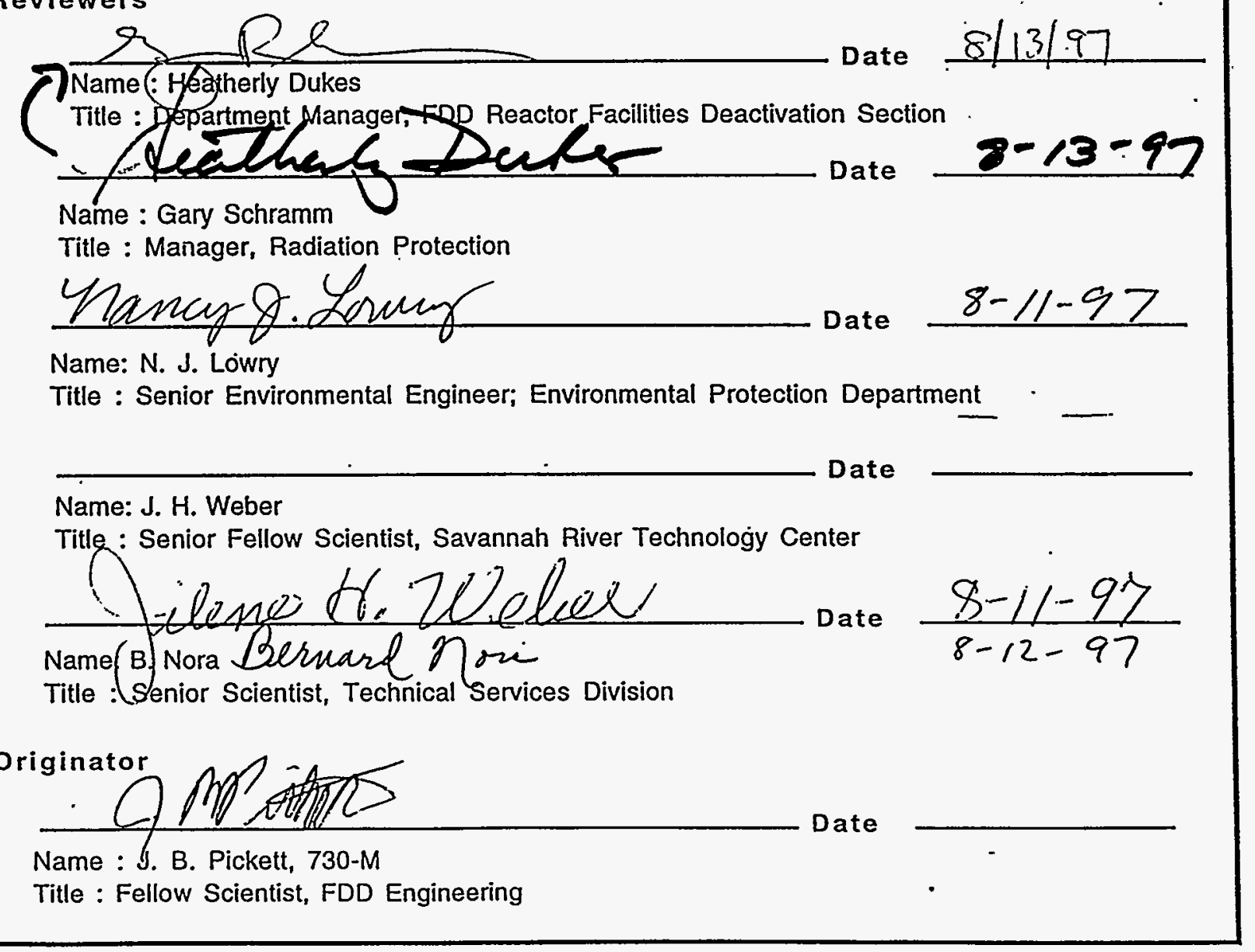




\section{R-REACTOR DISASSEMBLY SAMPLING PLAN}

\section{OBJECTIVE}

The R-Reactor Disassembly Basin is the largest disassembly basin in the 100 Areas, approximately 42,000 square feet, containing approximately 5 million gallons of water. The Facilities Decommissioning Division prepared a preliminary deactivation Plan for R-Building Disassembly Basin, which described the basin and presented a preliminary plan to deactivate the basin.

Deactivation of the basin is tentatively scheduled to begin in FY 99 to FY2000, and one of the initial activities is to sample the various areas and materials in the basin, in order to prepare a detailed deactivation program. The primary objective of this document is to present a sampling plan which will provide all of the information that will be required to prepare the detailed deactivation plan. A secondary objective is to confirm the presence of polychlorinated biphenyl compounds (PCB's), which were detected in one of two previous sampling campaigns.

\section{BACKGROUND}

Fuel and target assemblies were discharged from the reactor into the water filled disassembly basin. The reactor assemblies were initially stored in the Vertical Tube Storage (VTS), or Temporary Tube Storage, where the short-lived radionuclides decayed. The assemblies were then disassembled in the "Machine Basin" (MB), with the disassembled pieces stored in the "Bucket Storage" (BKS) and/or "Dry Cave Section (DCS) areas. Two other smaller areas, the "Monitor Pin Basin" (MPB) and the "Transfer Bay" (TB) are also included in the R-Reactor Disassembly Basin. The Emergency Disassembly Basin (EB) was the location of a 1957 experiment involving a fuel assembly inside a calorimeter, which ruptured during testing. In 1964 the Emergency Disassembly Basin was drained of water, backfilled with clay, and topped with a concrete cap. The areal extent, depth, and volume of each of these areas is summarized in Table 1.

During the basin's 10 years of use, and the subsequent 30 years of inactivity, a two to three inch layer of sludge has accumulated on the bottom of the basin. This sludge material and the water in the basin were sampled and analyzed in three previous sampling episodes.

\section{Previous Sampling Study Results}

The previous sampling campaigns were conducted to meet the objective of the Reactor Division Disassembly Management Plan, which was to transition the reactor basin to a Safe Storage Condition. The new sampling plan is more detailed, to meet the requirements of the proposed deactivation work. The results of the previous sampling programs are summarized in Reference 1.

\section{June 1994 - Initial Sludge and Liquid Samples}

Samples were collected from the Vertical Tube Storage (VTS), Machine Basin (MB), from locations in the Machine Basin immediately adjacent to the "closed" Emergency Basin (EB), and from the Transfer Bay (TB). The "Machine Basin" sample included samples locations from the BKS and DCS areas. The four areas were sampled from a total of sixty (60) different locations in the Disassembly Basin. One composite sample from each area was analyzed by SRTC for radionuclides, inorganic chemical constituents, and particle size distribution (on the solids fraction). Two composite samples from each area were transmitted to an off-site, certified laboratory for a full chemical analysis. In order to obtain the full inorganic and organic analyses desired, the composite sample from each of the four areas was combined by the laboratory. 
The two composites were separated into solids, approximately $1 \mathrm{wt}$. \% of the samples, and the associated "supernate". The only analytes of concern in the sludge layer from the initial sampling campaign were Arochor 1254 and lead. Cyanide was reported in the supernate associated with the solids, but was determined to be an analytical interference.

One liquid sample from the $\sim 5$ million gallon portion in the disassembly basin was sampled and analyzed for chemical constituents during this campaign. No constituents of concern were detected above the analytical detection limit, other than Aroclor 1254, in the low ppb levels.

The results from the initial sampling campaign are attached as Attachment I.

\section{January 1995 - Sludge Resample}

Sludge from three areas (VTS, MB, and TB) was re-sampled in January 1995, with a total of 47 sample locations used to prepare two composite sludge samples. The samples were analyzed using the Toxicity Characteristic Leaching Procedure (TCLP) and lead was shown to be less than the regulatory limit (Ref. 2). PCB's in the sludge layer was not re-determined, as an insufficient amount of solids were present in these samples to conduct the analysis.

December, 1996

A third sampling campaign was conducted in December of 1996. Four samples were collected from the liquid phase, and analyzed for PCB's. All four samples were less than the laboratory detection limit of $0.2 \mathrm{ppb}(\mu \mathrm{gm} / \mathrm{L})$. The results of the radioactive "screen" conducted by SRTC prior to offsite shipping are also given in Attachment $I$.

Table 1; Surface Area and Volume of R-Disassembly Basin Sections

\begin{tabular}{|c|c|c|c|c|}
\hline Basin Section & Area, $\mathrm{ft}^{2}$ & Depth, ft & Volume, $\mathrm{ft}^{3}$ & Comments \\
\hline Vertical Tube Storage (VTS) & 10,770 & 30 & 323,000 & - \\
\hline Emergency Basin (EB) & - & - & - & $\begin{array}{l}\text { Closed, Backfilled } \\
\text { in } 1964\end{array}$ \\
\hline Machine Basin (MB) & 7,970 & 19 & 151,000 & Has $3,50^{\prime}$ deep areas \\
\hline Dry Cave Section (DCS) & $9,720 * *$ & 18 & 175,000 & $\begin{array}{l}\text { Has } 1 \text { section } 30^{\prime} \text { deep; } \\
* * \sim 2,500 \mathrm{ft}^{2} \text { not } \\
\text { accessible to sample }\end{array}$ \\
\hline Bucket Storage (BKS) & 9,720 & 18 & 175,000 & . - \\
\hline Monitor Basin (MPB) & 425 & 17 & 7,222 & - \\
\hline Transfer Bay (TB) & 588 & $17-22$ & 11,300 & $\begin{array}{l}\text { Has } 2 \text { transfer pits, } 20 \text { and } \\
22^{\prime} \text { deep each }\end{array}$ \\
\hline
\end{tabular}




\section{SAMPLING PLAN SUMMARY}

Based on the previously collected data, and the objective of being able to prepare a deactivation plan for the R-Disassembly Basin, the following sampling plan is proposed.

The sampling plan is based on the assumption that the R-Reactor Disassembly Basin can be divided into three vertical strata, a shallow surface volume (1" to 6" in depth), the majority of the basin liquids (15' to $28^{\prime}$ in depth), and a shallow bottom "sludge" volume, 2 " to $3^{\prime \prime}$ in depth. The basin is further divided into 6 different areas, based on previous usage and size. Four of the larger areas, the Vertical Tube Storage (VTS), Machine Basin (MB), Bucket Storage (BKS), and Dry Cave Section (DCS) are subdivided into roughly 550 square foot areas. Each of these $550 \mathrm{ft}^{2}$ areas will be sampled, with four of the samples combined into composite samples. The individual samples will be collected from roughly the center of each sample area. If the radiation survey indicates a "hot spot" near the proposed sampling locations, or if the proposed location is in-accessible, the location will be shifted.

The two smaller areas - the Monitor Pin Basin (MPB), and the Transfer Bay area (TB) - will also be sampled four times, even though they are much smaller in area. The four samples will allow some statistical analysis of the constituent variation to be determined for those two areas.

\section{Radiation Survey}

Health Protection will conduct an extensive radiation survey of the entire basin, concentrating on the areas below water level. The objective is to provide an in-depth survey which will allow the sampling and the eventual deactivation activities to proceed with the minimum radiation exposure to the workers.

\section{Chemical and Radionuclide Analyses Sampling Strategy}

The sampling procedures and equipment, and laboratory analytical procedures will follow EPA SW 846 guidelines.

The sampling strategy assumes that the constituents of concern (primarily PCB's and radionuclides) may be distributed differently among the various basin areas, due to the different activities that occurred in those areas. It will be assumed that the constituents of concern are homogeneously distributed within each separate area, and that a "systematic" sampling scheme can be employed for each separate area.

The sludge layer samples will be composited from four different sample locations. This will;

- provide sufficient sludge solids to allow analytical determination of PCB's,

- reduce the volumes of liquids, and radionuclides, for shipment to the off-site Lab., and,

- minimize analytical costs.

The WSRC Environmental Protection Department (EPD) has provided guidance that the Environmental Protection Agency (EPA) believes that the presence of any one sample above the regulatory limit for PCB's $(50 \mathrm{ppm})$ defines that the entire system being sampled is therefore a TSCA waste. If therefore, any one composite sludge sample from any area fails the $50 \mathrm{ppm}$ limit, that area, and very probably the entire disassembly basin, will be considered a TSCA waste. The same logic would be applied if compositing were not used, i.e., if any one individual sample failed the $50 \mathrm{ppm}$ limit, that area, or the entire basin, would be a TSCA waste. The compositing technique will therefore provide sufficient data to determine the regulatory status and the subsequent deactivation needs. The EPA SW 846 sample location selection guidelines, which allow the calculation of a statistically "valid" mean and variance, were not utilized, due to the stringent "antidilution" TSCA interpretations. 


\section{Chemical and Radionuclide Analyses Sampling Summary}

\section{Surface Water Samples (1" to 2": of water at top of basin)}

Status; not previously sampled; no existing data.

A July, 1997 walkdown indicates that an "oil sheen" may be present on the surface.

The biological growth potential needs to be determined (nutrients, etc.)

Four surface water grab samples from entire basin will be analyzed for metals, anions, PCB's, Oil and Grease, TPH, BTEX, BOD, COD, and radionuclides.

\section{Liquid Samples ( $\sim 5$ million gallons present in basin)}

Status; only one sample was previously extensively analyzed. No constituents of concern detected. Four grab samples from the entire basin will be analyzed for metals, anions, PCB's, and radionuclides

\section{Sludge Samples for Composites ( 50,000 to 75,000 gallons sludge present at bottom of basin)}

Status; three areas (VTS, MB, and TB) were analyzed for chemistry and radionuclides by SRTC.

Two composites from the entire basin were analyzed for metals and organics by off-site lab. PCB's above the regulatory limit were detected in one of the two samples.

No information as to distribution of PCB's in the various basin areas is available.

Four individual sections will be sampled (MB, DCS, BKS, and MPB), two sections will be resampled (VTS and TB). One composite from each of these six sections, plus one composite from three $50^{\prime}$ deep pits in the MB, will be analyzed for metals, anions, PCB's, and radionuclides. This will provide a chemical and radionuclide characterization of each of the major sections in the basin.

Additional composites from each of the sections will be analyzed for PCB's (12 total). This will provide sufficient information to:

a) demonstrate that PCB's are NOT present above the regulatory limit in any (or all) area(s), or

b-1) if present in only one area, perhaps a plan to remediate only that area can be developed, or

b-2) develop a PCB remediation plan for the entire basin.

It should be noted that if one (or a very small number of the individual composite samples) fails (or passes) the regulatory limit for PCB's by a small margin, additional samples from that area may be needed to confirm the regulatory status.

Individual Sludge Location Samples

Eight of the 67 sampling locations will be individually sampled and "archived". These will be "archived" in case all of the composite samples pass the regulatory limit. These individual samples could then be used as additional confirmation that the sludge is NOT a TSCA/PCB waste. Collecting these individual samples while the composite samples are being collected will prevent the need to re-deploy the sampling equipment and personnel at a later time.

A detailed sampling and compositing plan is given in Table 2. 


\section{RADIATION SURVEY}

The radiation survey (Rad. Survey) will be conducted by Radiological Control technicians, using an RO7 detector. This will be lowered into the water, until 1-2 feet ABOVE the sludge layer. It is important not to disperse the sludge materials into the liquid phase, so that the liquid samples (to be taken after the Rad. Survey) are not impacted. It will be determined in the field what distance from the sludge provides the best compromise of radiation detection (vs. shielding by the water), with minimal disturbance of the sludge. If the radiation survey does disturb the sludge layer, it may be necessary to allow it to "resettle" before collecting the sludge samples.

The shallower portions of the basin (MPB, TB, DCS, BKS), should be surveyed first, then the 30 foot deep portions in the DCS, then the 30 foot deep VTS, and finally, three 50 foot vertical tube disassembly "pits" inside Machine Basin \#2 area.

A schematic drawing of each of the areas/sections will be provided by FDD Engineering to HP. The same drawings, with the proposed chemical sampling locations are given in Figures 3-8. If the Rad. Survey finds elevated radiation levels at a proposed sampling location, the sludge sample point will be moved to a lower radiation area.

The radiation technicians should survey as much of the underwater areas as possible, i.e.; all of those which can be accessed safely and without exposure to extensive removable contamination. Such areas should be indicated on the schematic drawings.

The $\mathrm{R} 07$ detector is a "mid-range" detector, $100 \mathrm{mrem} / \mathrm{hr}$ to $200 \mathrm{rem} / \mathrm{hr}$. A previous survey (Figure 2) found $<100 \mathrm{mrem} / \mathrm{hr}$ in the VTS section, and hot spots up to 75 and $134 \mathrm{R} / \mathrm{hr}$ in the DCS and MB areas. The R07 mid-range detector should therefore meet the survey needs. The technicians should move the detector along the floor of each area (1-2 feet above sludge), and record any readings above $100 \mathrm{mrem} / \mathrm{hr}$. on the schematic drawings. The detector should be moved slowly enough that any hot spots will have time to register. Fifteen to 20 feet per minute traverse is probably sufficient, but this can best be determined by the field technicians.

The detector should be left below the water level as much as possible, to minimize secondary waste from wiping the connector lines when the detector is raised.

Note; the results of a previous rad. survey, conducted in 1994, are given in Figure 2. 


\section{CHEMICAL AND RADIONUCLIDE SAMPLING LOCATIONS}

\section{Sludge Sampling Locations (2-3 Inch Deep Layer on Bottom of Basin)}

The objective of the sampling plan is to determine the key chemical and radionuclide compositions of the various sections in the R-Basin Disassembly Basin. The radionuclides, chemical analysis and particle size distribution in the sludge were previously determined for three areas in the basin. Additional radionuclide analyses will be conducted on one composite from each of the 6 areas to be sampled, plus one composite from the $50^{\prime}$ deep pits inside the Machine Basin. The primary objective of this sampling program is to determine the presence and concentrations of PCBs in the various areas, such that a suitable deactivation plan can be prepared. A "systematic random" sampling strategy was employed (Ref. 3).

A list of the various sludge sampling locations, by section, is given below in Table 2 . Schematic drawings showing the sludge sampling locations are given in Figures 3 through 8 . The specific sampling locations have been selected which avoid radioactive "hot spots" determined in a previous "rad. survey". The sampling locations will be modified as necessary when the "in-depth" Rad. Survey described in this plan is completed.

\section{Table 2; Number of Sludge Samples Per R-Basin Section}

$\begin{array}{ll}\text { Basin Section } & \begin{array}{l}\text { Number Sample No. Composites } \\ \text { Locations }\end{array} \text { Comments }\end{array}$

Vertical Tube Storage (VTS) $16 \quad 4$

Machine Basin (MB) $\quad 15 \quad 4$

Dry Cave Section (DCS) $\quad 12 \quad 3$

Bucket Storage (BKS)

16

Monitor Pin Basin (MPB)

some

Transfer Bay (TB)

Total
4

4

4

\section{3}

2

$\underline{2}$

19
Includes 3, 50' deep areas, which will each be sampled once; to make 1 composite

Fewer samples due to less area of liquid accessible

2 composites will allow variability to be determined

Has 2 transfer pits, each will be sampled once, plus a 2nd composite from the rest of the TB

Note, each sample location will correspond to approximately 550 square feet of underwater basin area. Fewer samples will be taken from the MB (smaller than the other areas), and the DCS (less accessible underwater area) to keep the average area per sample approximately equal. Even though the MPB and TB sections are much smaller than the other sections, 4 sample locations, and 1 composite per section will still be taken.

The number of sample locations is based on guidance provided by the EPA to support hazardous waste delisting petitions (Ref. 4). This reference provides guidance that, "in the case of a 40,000 square foot surface impoundment, to be $90 \%$ certain that $85 \%$ of the total population is less than the largest value obtained, a total of 15 random samples would need to be collected. To be $95 \%$ certain that $95 \%$ of the population is less than the largest value, 59 samples would need to be collected." This sample plan is a modification of the EPA guidance, in that a total of 67 locations will be sampled, with a total of 19 composites. 
Table 3: Sludge Sample Location Id and Composite Numbering

Basin Section

Vertical Tube Storage (VTS)

$$
\begin{aligned}
& 1,2,3,4 \\
& 5,6,7,8 \\
& 9,10,11,12 \\
& 13,14,15,16
\end{aligned}
$$

Composite No

VTS-COMP1

VTS-COMP2

VTS-COMP3

VTS-COMP4
Individual Sample Location

VTS-IND9

Machine Basin (MB)

$$
\begin{array}{lr}
1,2,3,4 & \text { MB-COMP1 } \\
5,6,7,8 & \text { MB-COMP2 } \\
9,10,11,12 & \text { MB-COMP3 } \\
13,14,15^{*} & \text { MB-COMP4 } \\
\text { * one each from } 50^{\prime \prime} \text { deep areas }
\end{array}
$$

DCS-COMP1

DCS-COMP2

DCS-COMP3

BKS-COMP1

BKS-COMP2

BKS-COMP3

BKS-COMP4

MPB-COMP1

MPB-COMP2

TB-COMP1

TB-COMP2
MB-IND2

MB-IND6

MB-IND10

DCS-IND3

BKS-IND7

MPB-IND4

TB-IND4

Transfer Bay (TB)

$$
\begin{aligned}
& 1,2, \\
& 3,4
\end{aligned}
$$

Surface Sampling Locations (Surface to 1-2 Inches Below Surface)

The surface strata is assumed to be homogenous throughout the entire basin. Four separate surface samples (grab samples) will be taken, one each in the VTS, MB, DCS, and BKS sections. Additional grab samples may be collected if significant differences are visible between the various areas (field determination).

Sample Id's will be VTS-SS, MB-SS, DCS-SS, and BKS-SS.

\section{Liquid Sampling Locations (Sub-Surface: Above Sludge)}

Four separate grab samples will be taken, one each in the VTS, MB, DCS, and BKS sections. Again, the liquid strata is assumed to be homogenous throughout the entire basin due to the long period of time for equalization to have occurred. These will be taken at a depth of approximately $1 / 2$ each section's depth, i.e.; 15-16 feet deep in the VTS section, and 8-10 feet deep in the other sections.

Sample Id's will be VTS-LQ, MB-LQ, DCS-LQ, and BKS-LQ. 


\section{SAMPLING METHODS AND EQUIPMENT}

\section{Sludge Sampling}

Due to the low solids contents of the sludge, it is planned to use a small submersible pump to collect the sludge samples. The submersible pump was selected due to the radioactive nature of the sampling locations. The pump can be transferred from one sample location to another, without pulling it up to the surface, as would be required for a "Coliwasa" type sampler, or a weighted bottle (Ref. 3). A pump such as "XP-060", which can pump up to 2 gallons per minute, at 50 foot depth, is suggested (Ref. 5).

Sampling protocols specified by the EPA (Ref. 6) indicate that PVC plastics such as Tygon® should not be used when sampling organic contaminants; rather Teflon $\otimes$ or Stainless Steel is to be used. Therefore, the tubing from the submersible pump to the sample collection bottle should be Teflon $B$.

It is expected that 4 to 5 gallons must be collected for each composite sample, in order to provide the laboratory with sufficient solids for each composite sample. It is proposed to use 15 gallon glass carboys to prepare the composite samples. For the 19 composite samples, 19 separate carboys would be used. The samples from each of the 4 (in one case, 3) sampling locations for each composite would be placed in one glass carboy. It is anticipated that some of the liquid portion above the sludge layer will be "pulled in" with the sludge, and disperse the sludge. Therefore, the samples will be allowed to stand, until a sludge layer settles out . The liquid above the sludge is to be decanted back to the basin, and the sludge sample transferred to the sample bottles provided by the analytical laboratory.

\section{Basin Liquid Sampling (4 Grab Samples)}

The submersible pump is to be used to collect the 4 liquid samples. The liquid will be transferred directly to the laboratory supplied sample bottles

\section{Basin Surface Sampling (4 Grab Samples)}

A swing sampler, similar to that depicted in Reference 5 (page 212) is recommended for the surface sample. The sample bottle(s) provided by the analytical laboratory can be attached to the sampling pole, which will allow the technicians to sample the surface from the edge of the basin, or from the overhead walkways.

\section{Equipment Cleaning Prior to Use}

Ten percent nitric acid is recommended (Ref. 6) for cleaning equipment to be used for sampling organics. The carboys and Teflon $®$ will be delivered to $315-\mathrm{M}$, and then cleaned and rinsed in the 341-M laboratory. The tubing and glass carboys are to be rinsed in the laboratory sink with $10 \%$ nitric acid solution (Reagent grade nitric acid + de-ionized water). The carboys are then rinsed with tap water, and finally rinsed with de-ionized water. The pump(s) is/are rinsed with tap water and then with de-ionized water. They will be allowed to air dry overnight. The openings are to be covered with Al foil, and then transported to R-Disassembly Basin. One sample of a carboy and tubing rinsate will be collected for laboratory analysis.

\section{SAMPLING PROCEDURES}

Surface Samples (4 grab samples)

As described above, the surface samples may be collected using a pole with an attached sample bottle. 


\section{Liquid Samples (4 grab samples)}

The submersible pump will be used to collect the 4 liquid samples first. The pump and tubing is to be flushed for 5 minutes, at least 2 gallons/min. flow rate, at each sample location - prior to obtaining the next liquid sample. The samples for PCB's must be shipped and extracted by the laboratory within 7 days. Holding time for the radioactive components is not specified, but it is planned to ship these samples with the other analyses requests. The radionuclide "EAV" analyses are normally completed with a 30 day turn-around.

\section{Sludge Samples (Composites)}

When possible, the submersible pump is to be moved to each new sampling location without removing it, or the attached tubing from the water. This will minimize radioactive exposure, contamination, and secondary waste generation. If necessary to remove the pump above the water level, Radiation Protection will specify the handling conditions.

Prior to collecting a sludge composite sample, the pump and tubing is to be "flushed" with 5 to 10 gallons of basin liquid. For example, after collecting the samples for Composite VTS-C1, from the VTS sample locations VTS-1, VTS-2,VTS-3, and VTS-4, the pump is to be raised to a depth of 1015 feet and flushed with 4 to 5 gallons of the basin liquid. The pump is then moved to sample locations VTS 5, 6, 7, and 8. The concentrations of the chemicals (including PCB's) in the liquid layer are 10 to 100 times less than in the sludge and the associated supernate. Flushing with the basin liquid will therefore adequately flush the submersible pump and Teflon tube before taking the next composite.

Since 4 sample locations are being combined into a composite, only minimal purging of the pump and line between each of these 4 locations is necessary. Simply turn the pump off, move to the new location, turn the pump on, allow the discharge to go back in the basin for 1-2 minutes, and then collect the sludge sample from the new location (into the sample collection container).

To minimize radiological exposure, the individual sludge sampling locations will be sampled using a smaller sample collection container. The following sampling procedure will be used:

- locate submersible pump at sludge sampling location,

- $\quad$ secure Teflon tubing to railing ("Duct" tape or other adhesive),

- $\quad$ place end of tubing into 2 or 4 gallon container (this may be plastic or glass),

- $\quad$ stand away from sample container (10" minimum preferable),

- turn on pump and fill container to shoulder,

- turn off pump, and check container with portable detector,

- $\quad$ if the sample is within the normal radiation readings (i.e.; no "hot particle" has been collected), then transfer the contents of the 2 or 4 gallon container to the 15 gallon carboy.

- If the sample is "too hot" to use, discard back to the basin, move the submersible pump, and repeat collecting that sample.

- Empty the sample collection container between the 4 locations for one composite; rinsing is not needed

- Empty and rinse the sample collection container between composites, using basin liquid.

The composite sample will be allowed to settle in the 15 gallon glass carboy, until a sludge layer at the bottom of the glass container is present.

Sludge Samples (Individual Sample Locations)

Eight individual samples, which are NOT composites, will be collected. At the sample locations shown in Table 3, eight to ten gallons of sludge will be collected from a single location, and placed in one 15 gallon carboy. The same sampling procedure, using the individual collection container technique described above will be used. The individual sample carboys will be retained for future analyses, if needed to confirm that PCB's are NOT present in the sludge layer. 


\section{INVESTIGATIVE DERTVED WASTES}

Since one of the previous sampling campaigns indicated that the sludge was higher than the PCB regulatory limit, any secondary wastes resulting from contact with the sludge must be managed as a radioactive $\mathrm{PCB} / \mathrm{TSCA}$ waste. It is critical to minimize the production of such waste., especially non-incinerable wastes. The only materials which should come in contact with the sludge are the small sample collection container, 15 gallon carboys, Teflon® tubing, and submersible pump. Per 40 CFR 761,60(c)(2), PCB contaminated containers below $500 \mathrm{ppm}$ may be emptied and disposed as non-PCB wastes. Therefore, when the sludge samples are transferred from the carboys to the laboratory bottles, empty the remaining sludge back to the basin. Flush the carboys with basin liquid water (which has been analyzed to be less than $0.2 \mathrm{ppb}$ PCBs, drain the carboys, and allow to dry. (up-side down), and discard as Low Level waste. Follow the same procedure for the small sample collection container.

Flush the submersible pumps and tubing with basin liquid, and then tap or distilled water, and retain for future sampling. Any Personal Protective Equipment (PPE) (gloves, wipes, etc.) which come in direct contact with the sludge is to be managed as PCB waste.

It is possible that the "oil sheen" on the surface may be contaminated with PCB's. Any waste, or samples of this material not sent off-site for testing, should be stored and managed as PCB waste. This would include PPE, or cloth wipes used to wipe equipment that has been in direct contact with the oily sheen/surface layer.

The PCB wastes must be stored in a DOT approved drum. Labeling of the drum must :

- use the EPA's "large PCB label" (stores No. 26.12970.00) on the drum,

- date waste was generated,

- description of contents, and

- weight of contents.

The drum must be transferred to the WSRC permitted PCB storage area within 30 days of the generation of the first PCB waste. If it is determined that the surface layer is NOT a PCB waste, then EPD will be requested to re-label the container, and dispose as low level waste. 


\section{RADIATION SCREENING SAMPLES}

The previous 4 composite sludge samples analyzed by SRTC were similar to each other in radionuclide levels (Attachment I, Table 1), except that the Machine Basin and Emergency Basin samples were higher than the other two areas. Radiation Screening results on the liquid sample collected in December 1996 are also included in Attachment I. These results on the liquid portion is considered to be sufficient for shipping and receipt by the laboratory, but a limited number of screening samples on the sludge are needed to confirm the previous results. The new sludge samples will also be calibrated vs. a field count rate meter. If the field meter is within a factor of two, vs. the screening samples, the screening sample results will suffice to ship the sample. If higher than a factor of 2 , a new rad. screen may be needed prior to shipping.

\section{Radiation Screening; Surface Samples (2 Grab Samples)}

Two samples should be collected from the surface, one from the east end, one from the west end of the basin, perhaps using a pole and bottle sampler. Floating "scum" or algae, if present, is to be included. The samples are each to be mixed/ homogenized by SRTC prior to running the Rad. Screen. Sampling for the off-site lab. samples is not to start until the rad. screen results are completed, due to the 7 day hold time restriction for PCB's.

\section{Radiation Screening: Liquid Stratum}

Previous Radiation Screening on the liquid stratum in the basin provide sufficient information for off-site shipping and laboratory receipt. No additional rad. screening on the liquid layer is planned.

\section{Radiation Screening; Sludge Samples (4 composites from VTS, MB, DCS, and BKS)}

Four sludge samples will be collected, one each from the VTS, MB, DCS, and BKS sections. A similar sampling technique using the submersible pump and the 10-15 gallon carboys is to be used. The pump used for the liquid rad. screen sample can be used for the sludge rad. screening samples. Three or four different locations in each section is to be sampled, placed into one carboy, and allowed to settle. Settling may take 24-72 hours.

The settled solids for each Rad. Screening sample will be monitored by Radiation Protection to determine the radiation $(\mathrm{c} / \mathrm{m})$ at a specific, consistent distance (surface of container, or 3 " away) from the settled sludge. These readings will be compared to the settled solids to be shipped for offsite analyses, to ensure that the Rad. screening results are consistent with the collected samples.

The settled solids will be transferred to SRTC for Rad. Screening. Note, the same sampling procedures as discussed previously for the sludge samples will be used.

The SRTC Laboratory is to homogenize each composite, and determine the radioactive components. A separate determination of the rad. screen on the solids and supernate portions in the sludge is NOT needed for shipping and off-site Laboratory receipt. 
FDD ENGINEERING

R-DISASSEMBLY BASIN

RADIATION SURVERY AND SAMPLING PLAN
FDD-ENG-97-0044, Rew/

REVISION NO. : $\theta$

AUS? 13,1997

PAGE 14 OF 24

4) 198 IIP

FIGURE 1

RADIATION SCREENING SAMPIES AND OFF-SITE SAMPIING SCHEDULE

RADIATION SCREENING SANRLES SRTC

2 SURFACE SAMPLES; EAST/WEST IN BASIN
TO SRTC FOR

RAD. SCREEN
OFF-SITE SAMPIES

GEL
IIQUID IN BASIN

PREVIOUS DATA SUFFICIENT

FOR OFF-SITE SHIPPING

NO RAD. SCREEN NEEDED
SAMPLE AFTER SURFACE SAMPIING COMPLETE ( 7 DAY HOLD

TIME FOR PCB ANAIYSIS).

USE NEW PUMP AND TUBING.

4 GRAB SAMPLES (NOT COMPOSITED)
4 COMPOSITE SLUDGE SAMPLES, ONE EACH VTS, MB, DCS, \& BKS.

USE PUMP FROM LIQUID SAMPLING, LET SETTLE 24-72 HRS.

$\frac{\text { TO SRTC FOR }}{\text { RAD. SCREEN }}$

WAIT UNTIL SAMPLE FOR RAD. SCREEN SENT TO SRTC BEFORE STARTING SLUDGE SAMPLING.

LET SLUDGE

SETTLE IN CARBOYS UNTIL CONCENTRATED ENOUGH TO SHIP.

7 DAY HOLD TIME STARTS WHEN SETTLED SAMPLE TAKEN FROM CARBOY.

19 COMPOSITE SAMPLES 
FDD Engineering

R-Disassembly Basin $4 / 08 / 98$

Radiation Survey and Sampling Plan

\section{ANALYSES AT OFF-SITE LABORATORY}

\section{Surface Samples (4 Grab)}

Biological contamination is suspected, due to the appearance of the surface liquid. The potential for algae growth, if the lighting is increased during the deactivation activities, is of concern. The samples should be mixed/homogenized by the laboratory prior to conducting the chemical and radionuclide analyses. The following analyses are needed, on each of the 4 samples:

Wt \% solids $\left(105^{\circ} \mathrm{C}\right)$, TSS, TDS, TOC, BOC, COD, \% oil and grease, TPH, BTEX, and pH, Particle size distribution (PSD), of the suspended solids, without filtration or drying, if possible, Anions (bromide, chloride, nitrate as N, nitrite as N, phosphate, sulfate),

ICP Scan plus $\mathrm{Be}, \mathrm{Cd}, \mathrm{Co}$, and $\mathrm{U}$

Pesticides/PCB Scan (2 ppm detection limit)

Plus the 22 radionuclide "EAV" scan, plus tritium (if not part of EAV scan)

\section{Liquid Samples (4 Grab)}

$\mathrm{pH}$,

ICP scan, plus U

anions (bromide, chloride, nitrate as $\mathrm{N}$, nitrite as $\mathrm{N}$, phosphate, sulfate),

Pesticides/PCB, (0.2 ppb detection limit),

Plus the 22 radionuclide "EAV" scan, plus tritium (if not part of EAV scan)

Sludge Samples ( 7 composites; 2 from MB, one each from other 5 sections )

$\mathrm{pH}$ and wt. \% solids $\left(105^{\circ} \mathrm{C}\right)$

Samples to be mixed/homogenized and reported at $\mathrm{mg} / \mathrm{ml}$ for

- ICP scan, plus B, Be, Cd, Co, Si and U, and

- anions (bromide, chloride, nitrate as $\mathrm{N}$, nitrite as $\mathrm{N}$, phosphate, sulfate),

- Plus the 22 radionuclide "EAV" scan, plus tritium (if not part of EAV scan).

Pesticides/PCBs, (2 ppm detection limit ) Note; if the weight $\%$ solids is above $0.5 \%$, then the solids must be separated from the liquid portion, prior to PCB analysis,

Sludge Samples (12 composites; 3 each from VTS, and BKS, 2 each from MB and DCS, and 1 each from MPB and TB areas)

$\mathrm{pH}$ and wt. \% solids $\left(105^{\circ} \mathrm{C}\right)$

Pesticides/PCBs, (2 ppm detection limit ) Note; if the weight $\%$ solids is above $0.5 \%$, then the solids must be separated from the liquid portion, prior to $\mathrm{PCB}$ analysis.

\section{Quality Assurance Samples}

The analytical laboratory is being provided with sufficient sample volumes to conduct the internal laboratory QC/QA controls on the ICP scan, Pesticides/PCB's, and radionuclide analyses, such as duplicates and matrix spike. In addition, the following QA samples will be conducted:

- 2 samples of equipment rinses for Pesticides/PCB's

- 1 Duplicate Sample from any basin liquid location, identified as

- "Duplicate Sample for GEL Matrix Spike", analyze for Pesticides/PCB's

- 3 Trip Blanks, one each for surface water, basin water, and sludge, analyze for all constituents indicated for the various sample types (surface water, basin water, and sludge).

- 1 Preservative Blank. Sample bottle for inorganic analysis, with metals preservative added, will be filled in the field with distilled water. This will be labeled "Inorganic Preservative Blank". 
Definitions and Acronyms

Sludge

Supernate

For this study, the sludge is defined as the 2 to 3 inch deep layer of material at the bottom of the Disassembly Basin. Previous analyses indicated $\sim 1 \%$ total solids.

Basin Liquid The majority of the liquid in the basin, above the sludge layer to the surface.

Basin Surface This top layer of liquid in the basin, which has an "oil sheen" and some organic matter (Algae, etc.,). The depth of this layer has not been determined, but is expected to be no more than 1-2 inches.

$\begin{array}{ll}\text { BOD } & \text { Biological Oxygen Demand } \\ \text { BETX } & \begin{array}{l}\text { Benzene, Ethylbenzene, Toluene, and Xylene } \\ \text { Chemical Oxygen Demand }\end{array} \\ \text { COD } & \text { U. S. Environmental Protection Agency } \\ \text { EPA } & \text { General Engineering Laboratory, Charleston, SC } \\ \text { GEL } & \text { Polychlorinated Biphenyl compounds } \\ \text { PCB's } & \text { Personal Protective Equipment } \\ \text { PPE } & \text { Polyvinyl Chloride } \\ \text { PVC } & \text { Total Dissolved Solids } \\ \text { TDS } & \text { Total Petroleum Hydrocarbons } \\ \text { TPH } & \text { Total Suspended Solids } \\ \text { TSS } & \text { Savannah River Technology Center }\end{array}$

Sample Areas

VTS

$\mathrm{MB}$

BKS

DCS

MPB

TB
Vertical Tube Storage

Machine Basin

Bucket Storage Section

Dry Cave Section

Monitor Pin Basin

Transfer Basin 


\section{REFERENCES}

1. J. B. Pickett to C. W. McMullin, "Summary of R-Disassembly Basin Analytical Data, and Preliminary Proposed Treatment Options (U)", FDD-ENG-97-0007, Rev. 1, 4/13/98.

2. J. H. Spears to B. L. Westover, "Re: Job 94367, Water Samples from K, L, P, C, and R Disassembly Basins" 2/23/95.

3. "Waste Analysis at Facilities That Generate, Treat, and Dispose of Hazardous Wastes, A Guidance Manual", PB94-963603, U. S. EPA, Washington DC, April, 1994.

4. M. Morse, J. Warren, and W. Sproat, "Sample and Analysis for Delisting Data Verification/ Delisting Spot Checks, Proceedings of the 2nd U. S. EPA Symposium on Solid waste Testing and Quality Assurance, Washington, DC, July 15-18, 1986.

5. Forestry Suppliers Inc. Catalog, 1997.

6. "Environmental Compliance Branch Standard Operating Procedures and Quality Assurance Manual, U. S, EPA, Region IV, Athens, GA, 2/1/1991. 


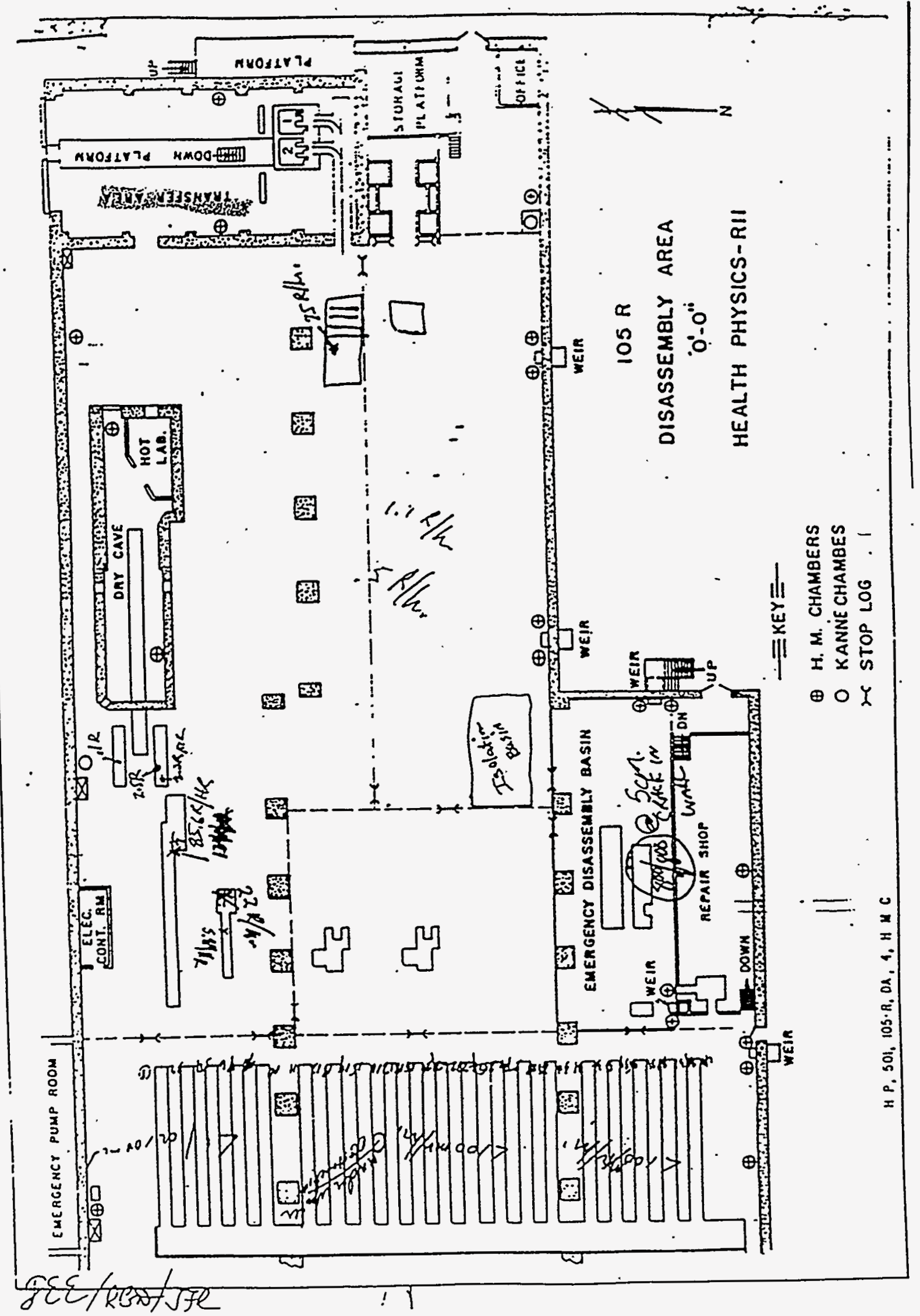

Figure 2, Results of 1994 Radiation Survey 
(공

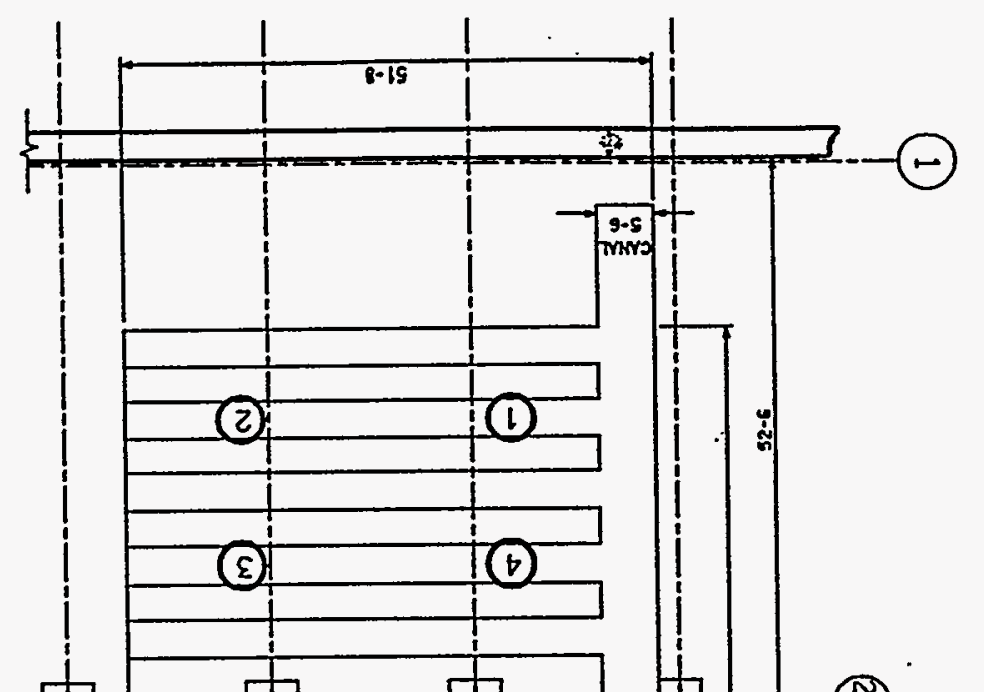

$\frac{z}{n}$

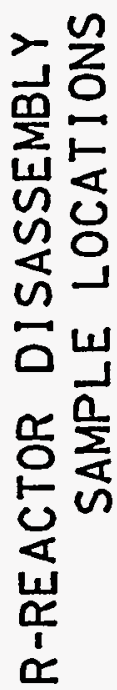

直
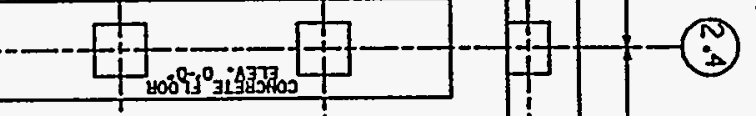

范

.

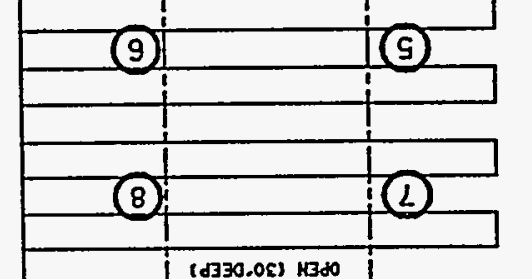

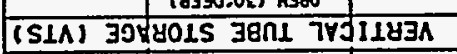
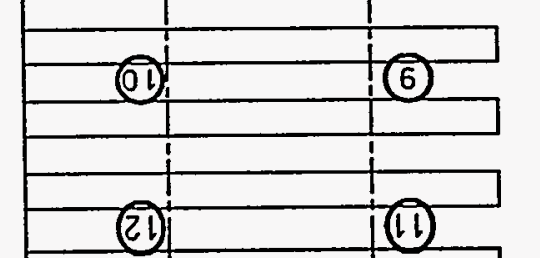

(11)

:

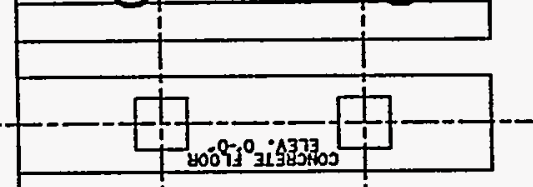

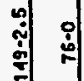
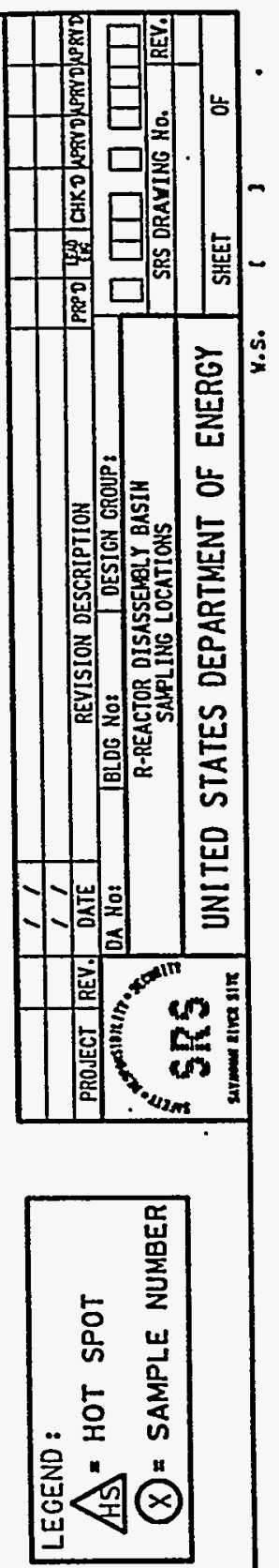

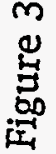

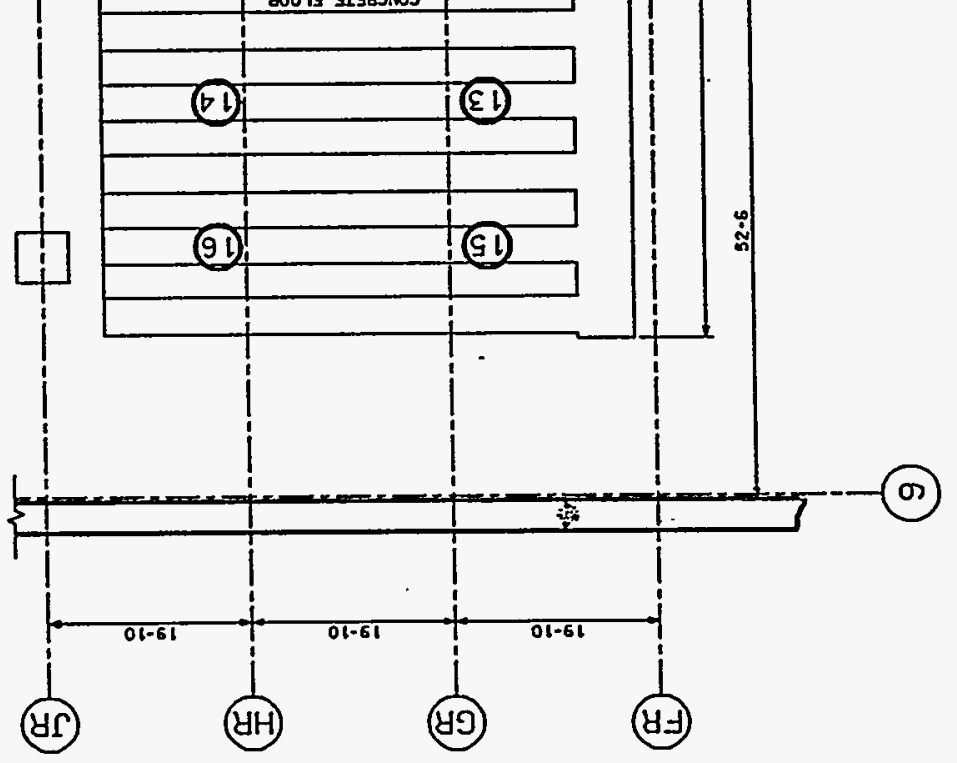

$\stackrel{\Xi}{\bar{x}}$ 

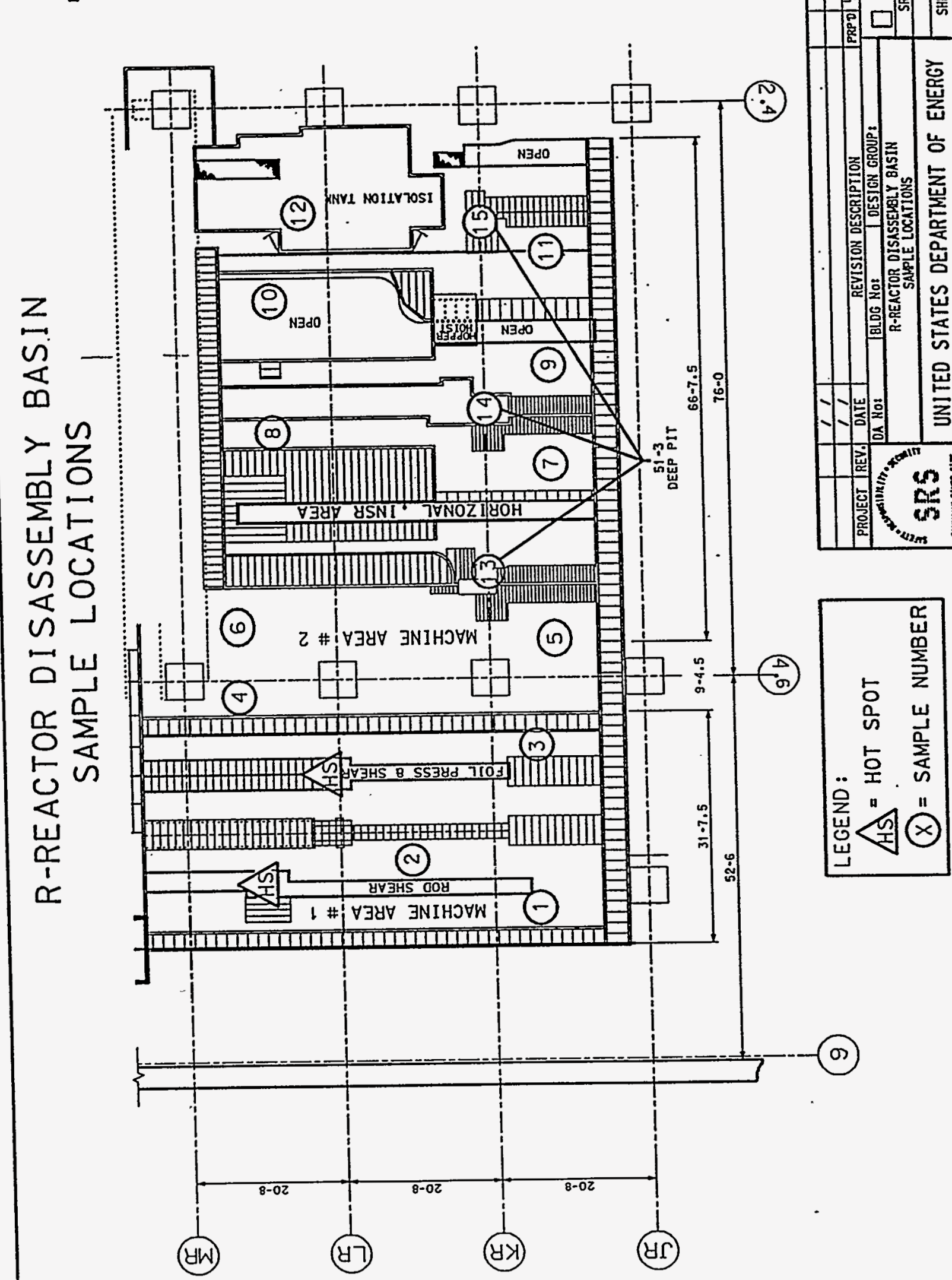


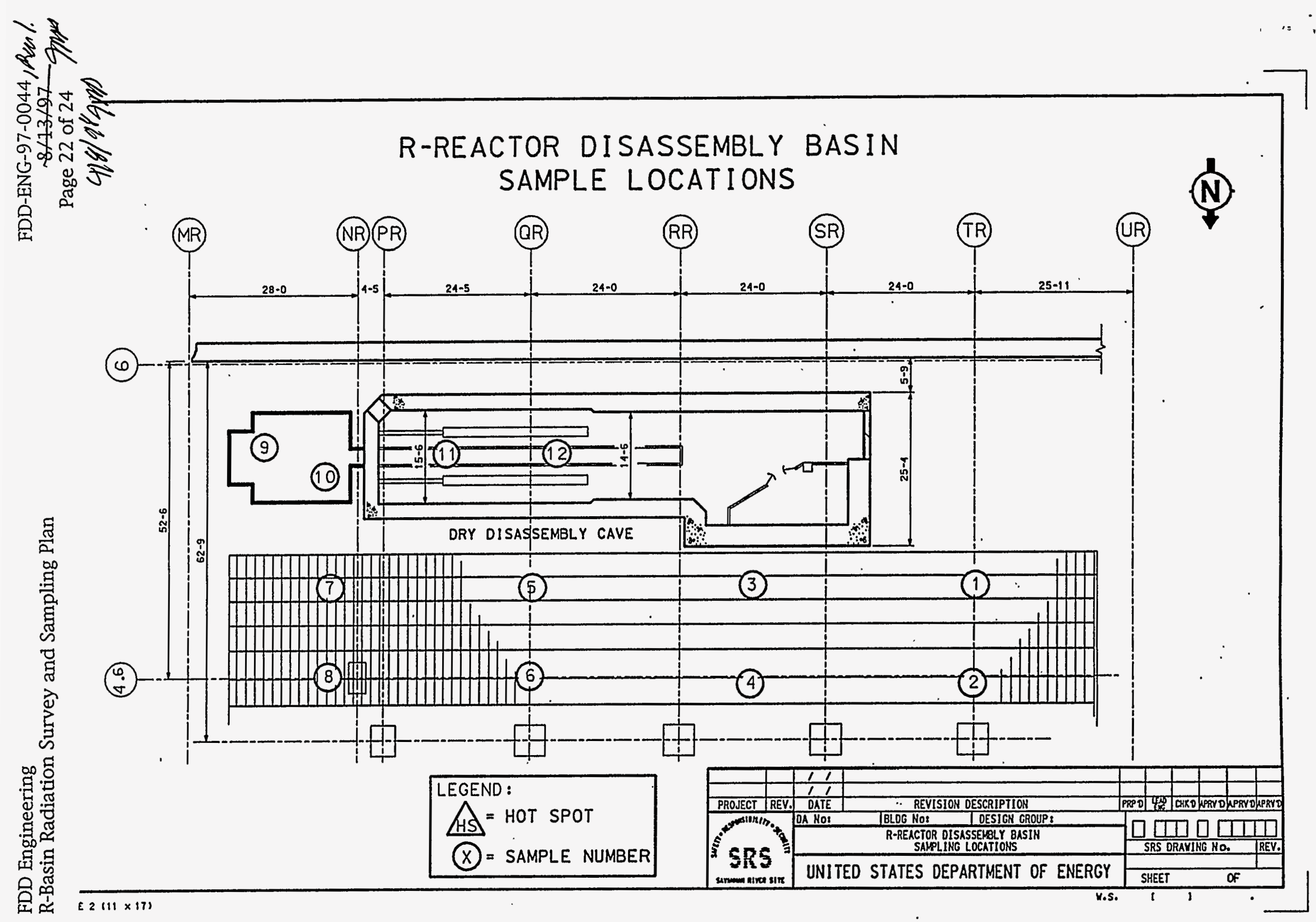

Figure 6 
s

\section{R-REACTOR DISASSEMBLY BASIN} SAMPLE LOCATIONS
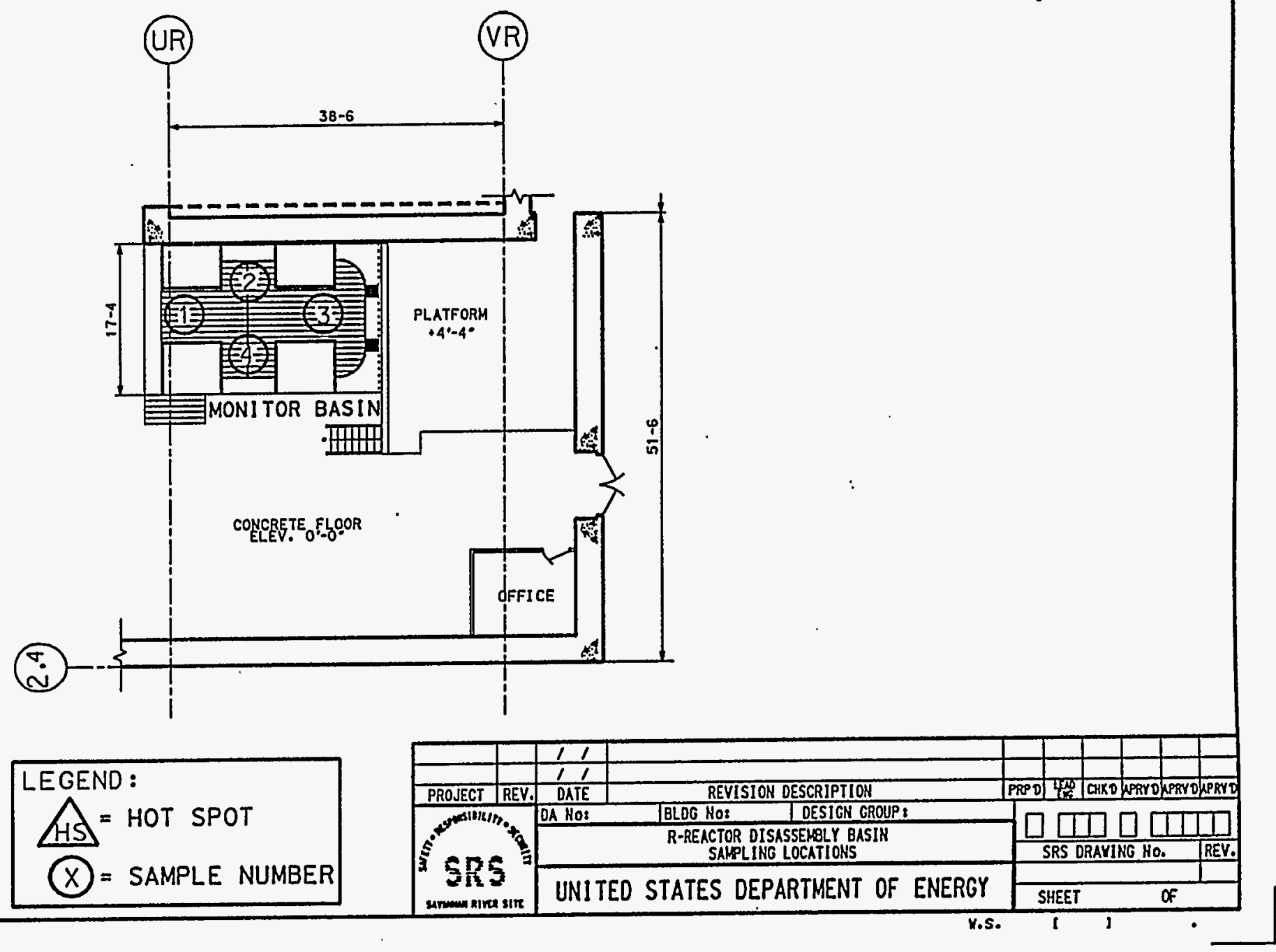


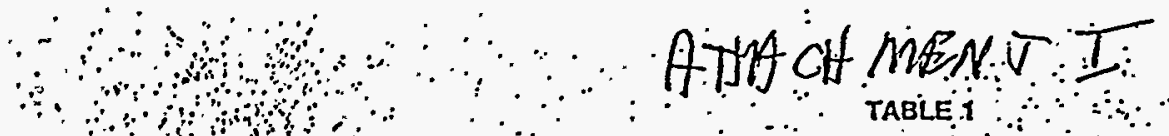

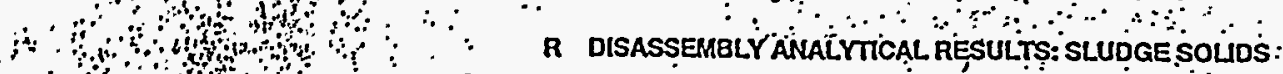

$\therefore$ Sampioio

$\because$ Láboratón

Dato Sámplád

\begin{tabular}{|c|c|c|c|}
\hline $\begin{array}{c}\text { CVIS-1 } \\
\text { SATC } \\
8 / 94\end{array}$ & $\begin{array}{l}\text { CNB-1 } \\
\text { SRाC } \\
\text { 8/94 }\end{array}$ & $\begin{array}{l}\text { CTB-1. } \\
\text { SRTC. } \\
8 / 94^{\circ} .\end{array}$ & ${ }_{8 / 94}^{\text {CEB-1 }}$ \\
\hline 1.00 & 1.06 & 0.70 & 0.09 \\
\hline 21.6 & 22.3 & 18.8 & 18 \\
\hline 13 & 1 & 114 & \\
\hline
\end{tabular}

$8 / 4 / 9$

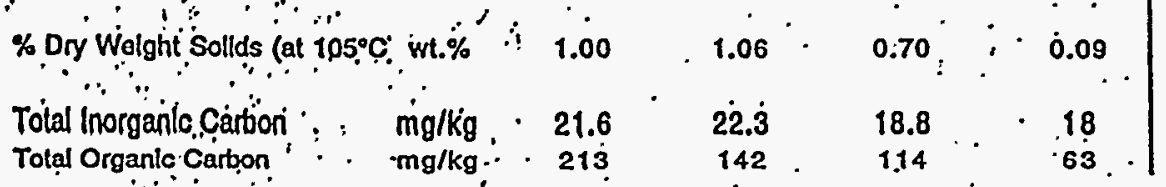

Total. Constttuent Concentration

Total Metals; (dry wt. ):

A

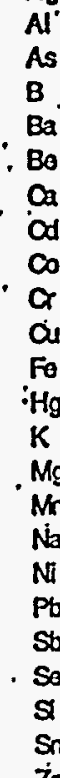

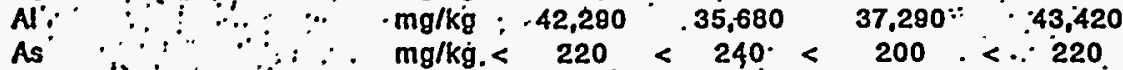

Dry wt. Basis". $\quad \therefore$.1. AVERAGE

$\therefore \begin{gathered}\text { 101900: } \\ \text { CTC: } \\ \text {.7194: }\end{gathered}$

is

$0.71 \cdot \cdots \quad \mathrm{NR}$

$\therefore N$

Finting

$\mathrm{mg} / \mathrm{kg} .<220<240^{\circ}<200 .<220<<39,670$

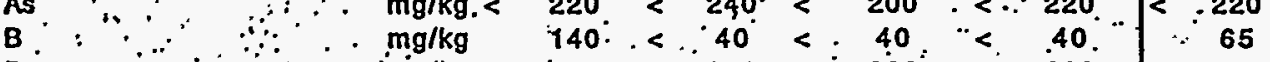

Bo,$\because$, mg/kg

a $\because \because, \therefore \quad \mathrm{mg} / \mathrm{kg}$

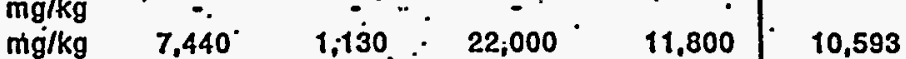

$\mathrm{K}$

$\therefore \quad \cdot m g / k g$

$\because \quad \mathrm{mg} / \mathrm{kg}<40^{\circ}$

$\mathrm{mg} / \mathrm{kg}$
$\mathrm{mg} / \mathrm{kg}$$\frac{40}{180}$

$\therefore \begin{array}{ll}\mathrm{mg} / \mathrm{kg} \\ \mathrm{mg} / \mathrm{kg} \\ \mathrm{mg} / \mathrm{kg}\end{array}$

mg/kg. $\quad 324,000$

$40 \div 50<10^{\circ}$

$40<40$

$250 \div 80 \cdots 40$

$230<10 \cdot 190$

$<30$

$\mathrm{mg} / \mathrm{kg}$

0.6 .

397,000

322,550 :

345,220

175

80 .

$\mathrm{mg} / \mathrm{kg}$

0.5 .0 .1 .

0.1 :

347,193

$\begin{array}{lllll}\mathrm{mg} / \mathrm{kg} & 3400 & 1930 & 2560 & 2820 \\ & 3450 & 7670 & 2370\end{array}$

$\cdot \mathrm{mg} / \mathrm{kg}<110<120<100<110$

$\mathrm{mg} / \mathrm{kg}$.

$\mathrm{mg} / \mathrm{kg}<220<240<200$

$\cdot \mathrm{mg} / \mathrm{kg}<-\dot{\mathrm{mg} / \mathrm{kg}}<1120<1180<1002<1090<1098$

$\mathrm{mg} / \mathrm{kg} \quad 68,160 \quad 43,870 \quad 46,830$

$\mathrm{mg} / \mathrm{kg}<.80$

$\mathrm{mg} / \mathrm{kg}$

29,800

$\begin{array}{cc}70 & <0 \\ 25,130 & 7.188\end{array}$

67,690
80
20,980

0.33

2465

< 110.

245

So

Sn

CVTS=Vertical Tube Storage Bașin; $C M B=$ Machine Basin; $C T B=$ Transfer Bay; CEB $=$ Emergency Basin

-CTC = Clemson Tectinical Center, Rust Remedial Services

Semivolatile Organics

\begin{tabular}{ll}
\hline $\begin{array}{l}\text { Phenanthrene } \\
\text { Fouranthene }\end{array}$ & $\begin{array}{l}\mathrm{mg} / \mathrm{kg} \\
\mathrm{mg} / \mathrm{kg}\end{array}$ \\
Pyrene. & $\mathrm{mg} / \mathrm{kg}$. \\
Bis(2-ethylhexyl) phthalate, & $\mathrm{mg} / \mathrm{kg}$ \\
Butylbenzyl phthalate & $\mathrm{mg} / \mathrm{kg}$ \\
Benzo(a)anthraciene & $\mathrm{mg} / \mathrm{kg}$ \\
Chrysene & $\mathrm{mg} / \mathrm{kg}$ \\
Cyclöhexanone & $\mathrm{mg} / \mathrm{kg}$ \\
Isophorone & $\mathrm{mg} / \mathrm{kg}$ \\
Benzo(k)fluoranthene & $\mathrm{mg} / \mathrm{kg}$ \\
Benzo(a)pyrene'. & $\mathrm{mg} / \mathrm{kg}$ \\
Phosphoric acid, & $\mathrm{mg} / \mathrm{kg}$ \\
tris(2-ethylhexyl)ester & \\
& \\
Pesticides and PCBs & \\
\hline PCB 1254 & $\mathrm{mg} / \mathrm{kg}$ \\
PCB 2346 & $\mathrm{mg} / \mathrm{kg}$ \\
PCB 3344 & $\mathrm{mg} / \mathrm{kg}$ \\
PCB 23445 & $\mathrm{mg} / \mathrm{kg}$ \\
PCB 23456 & $\mathrm{mg} / \mathrm{kg}$. \\
PCB 22446 & $\mathrm{mg} / \mathrm{kg}$ \\
PCB 22455 & $\mathrm{mg} / \mathrm{kg}$ \\
PCB 233445 & $\mathrm{mg} / \mathrm{kg}$ \\
PCB 334455 & $\mathrm{mg} / \mathrm{kg}$
\end{tabular}

GCMS Volatile Organics

Organophosphate Pesticides

Chlorinated Herbicides

Dioxans/Furans

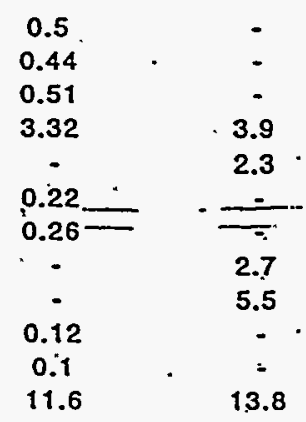

$\begin{array}{cc}15.2 & 99.2 \\ - & 2.2 \\ - & 3.8 \\ - & 2.9 \\ - & 4.1 \\ - & 4.9 \\ - & 4.5 \\ - & 2.3 \\ - & 2.1\end{array}$

None Detected above detection limits None Detected above detection limits None Detected above detection limits None Detected above detection limits 
TABLte $t$ Cont

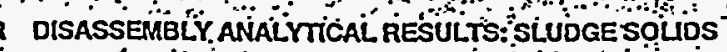

Samplo 10"\#

Laboratory

- Dáto Samplod

Totáal Aphá

Total bota/garma

Trtium.

có-60

Am-241

Th-232

U-235

Rádionuclide Analyses:

CVTS:1 SiRtc.

CMB-1
SFIC

CTB-1

average

स्EB-1

$$
\text { शार . . } \because
$$

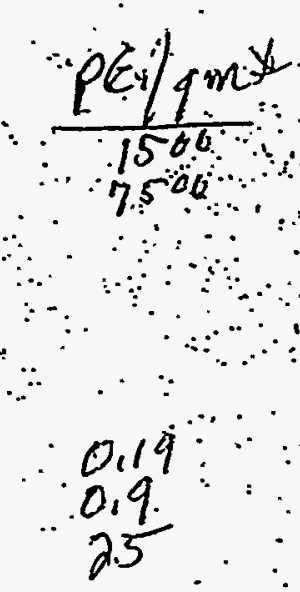

$$
\begin{aligned}
& 3100 \mathrm{~d} / \mathrm{m} / 9 \mathrm{~m} \\
& \text { 2. } 2 \times 10^{12} \text { dis/minlci } \Xi j 500 \text { ti tgm } \\
& \cong 1500 \times 10^{-12} \mathrm{ci} / \mathrm{gm} \\
& =
\end{aligned}
$$

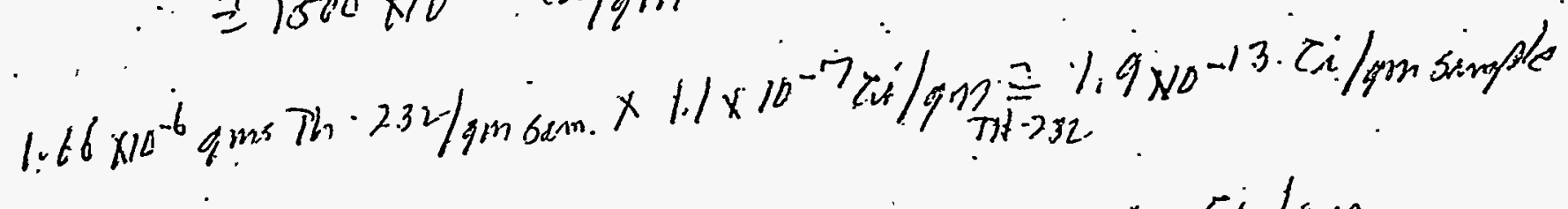

$$
\begin{aligned}
& =0.19 p^{c i} \lg m \\
& 0.37 \times 2.6 \\
& 6.39 \times 10^{-6} \times 2.2 \times 10^{-6}=0.9 \times 10^{-12} \text { ci } / q_{10}=0.9 p \text { cin } / q^{m} \\
& 73.8 \times 10^{-6} \times 3.4 \times 10^{-7} \cong 250 \times 10^{-13}=25 \mathrm{pti} / \mathrm{gm}
\end{aligned}
$$


TABLE 2

R DISASSEMBLY ANALYTICAL RESULTS: SLUDGE SUPERNATE and LIQUID

Laboratory

Sample ID \#

Date Sampled

Total Metals

Ag

Al

As

$\mathrm{B}$
$\mathrm{Ba}$

$\mathrm{Be}$

$\mathrm{Be}$

cd

co

$\mathrm{Cr}$.

$\mathrm{Fe}$

$\mathrm{Hg}$

$\mathrm{K}$

$\mathrm{Mg}$

$\mathrm{Mn}$

$\mathrm{Ni}$

$\mathrm{Pb}$

$\mathrm{Sb}$

se

$S$

Sn

$\mathrm{Zr}$

$\mathrm{pH}$

Anions

$\mathrm{NO3}$

$\mathrm{NO} 2$

$\mathrm{SO}_{4}$

$\mathrm{PO} 4$

$F$

$\mathrm{a}$
$\mathrm{C} 2 \mathrm{O} 4$

$\mathrm{CO} 3$

Cyanide

$\begin{array}{crrr}\text { SHTC } & \text { SRTC } & \text { SRTC } & \text { SRTC } \\ \text { CVTS-1 } & \text { CMB-1 } & \text { CTB-1 } & \text { CEB-1 } \\ 8 / 94 & 8 / 94 & 8 / 94 & 8 / 94\end{array}$

"Supernate" in Contact With Solids in the Sludge Layer

\begin{tabular}{c|cc|cccccc} 
SRTC & CTC & CTC & CTC & CTC & CTC & CTC & CTC & GEL." \\
Average & 101900 & 101901 & 101902 & 101906 & 101911 & 101912 & 101913 & R-Basin \\
& $7 / 94$ & $7 / 94$ & $7 / 94$ & $7 / 94$ & $7 / 94$ & $7 / 94$ & $7 / 94$ & $1 / 97$
\end{tabular}

Liquild Above Sludge

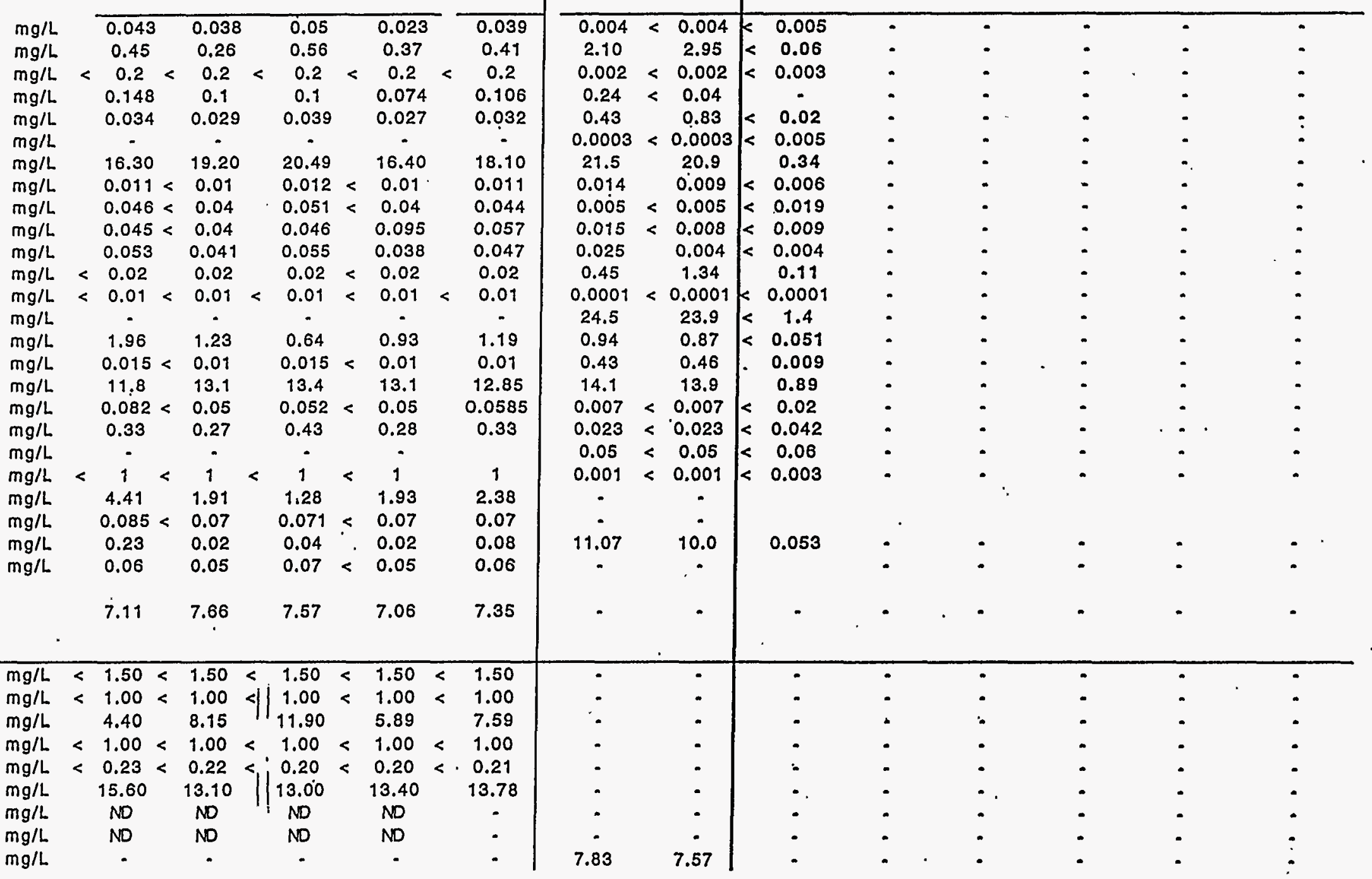

-CTC = Clemson Technical Center, Rust Remedlal Services, Clemson, SC

* GEL = Genesal Engineering Laboratory, Charleston, SC 
"Supernate" in Contact With Sollds In the Sludge Layer
Laboratory

Sample ID \#

Date Sampled

Pesticides and PCBs

PCB 1254

\begin{tabular}{crrr}
\multicolumn{5}{c}{ "Supernate" in Contact with Soll } \\
\hline SRTC & SRTC & SRTC & SRTC \\
CVTS-1 & CMB-1 & CTB-1 & CEB-1 \\
$7 / 94$ & $7 / 94$ & $7 / 94$ & $7 / 94$
\end{tabular}

Note, 4 adoitional supernale samples a

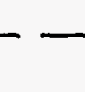

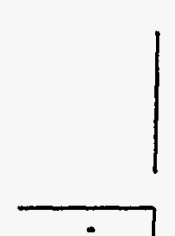

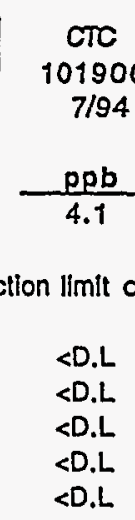

Liquild Above Sludge

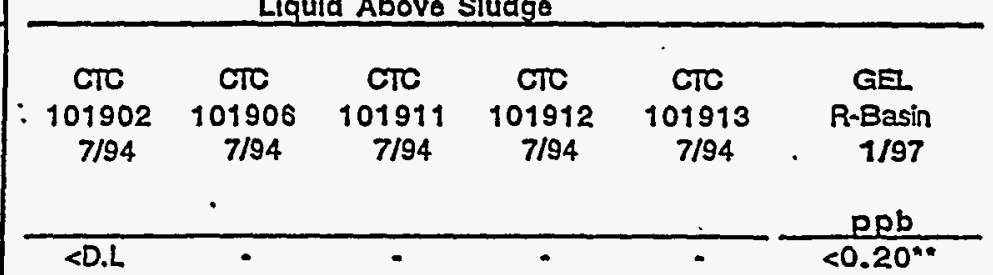

GC/MS Volatile Organics

Semivolatile Organics

Organophosphate Pesticides

Chlorinated Herbicides

Dioxans/Furans

"-" means Not Analyzed

. 4 liquid samples analyzed by GEL $1 / 97$, none above 0.2 ppb Detection Limit

Radionuclide Analyses (Liquid in Contact with Sludge Solids)

$$
\text { SRTC }
$$

Average

Total Alpha
Total beta/gamma $\left.(4) / 0 T_{3}\right)$ !

70

130

94

244

108

62

$\mu \mathrm{Cl} / \mathrm{ml}$

$0.041^{0.041^{\circ}} \quad 0.04$

0.041

$\begin{array}{ccccc}N D & N D & N D & N D & N D \\ N D & 0.0001 & 4 E-05 & 0.0001 & 0.00008 \\ N D & N D & N D & N D & N D\end{array}$

Co.60

Cs. 137

Am-241

$\mu \mathrm{Cl} / \mathrm{ml}$ $\mu \mathrm{Cl} / \mathrm{ml}$ $\mu \mathrm{Cl} / \mathrm{ml}$

\section{$\mathrm{d} / \mathrm{m} / \mathrm{ml}$}

\author{
lids)
}

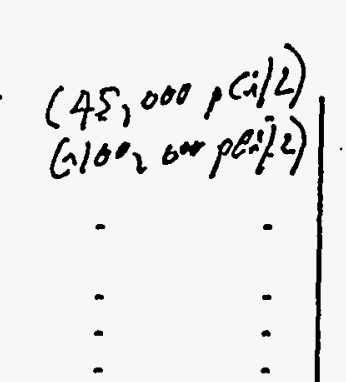

\#, Data per John Hage, SATC, 5/97

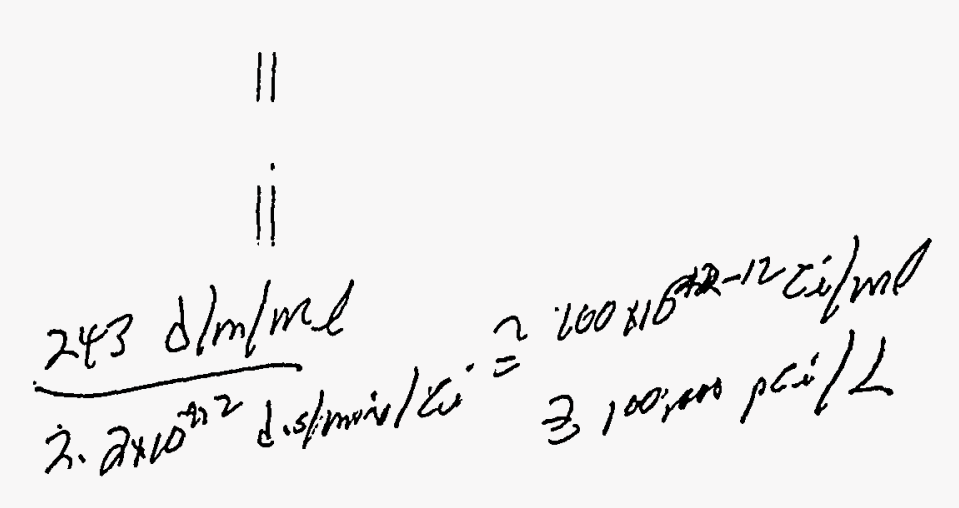

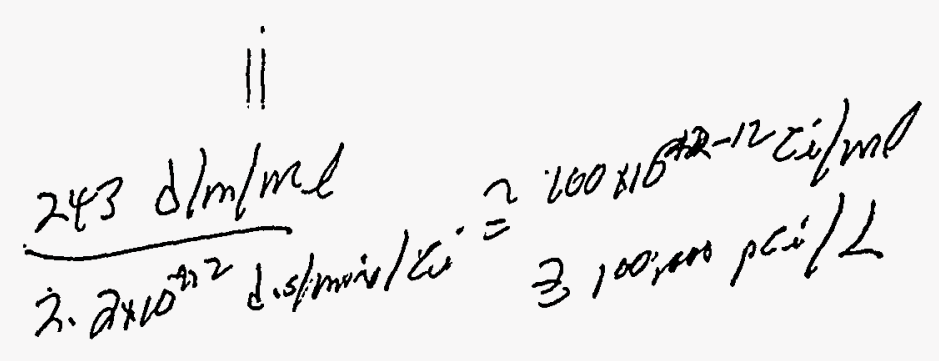

- Llquild Above Sludge.

ज्राC 96417-1R $12 / 96$

160 88,000 se $+5 x$

0.039 $0.00011 *$

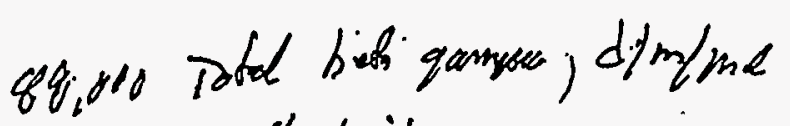

$$
\begin{aligned}
& \text { 29\% Xnifition } \\
& 2240 \mathrm{~d} / \mathrm{m} / \mathrm{ml} \text { wo tritions. }
\end{aligned}
$$

